\title{
Leptospira, the ocular predator
}

Sangeetha Subramaniam ${ }^{1,2}$, Anhar Hafiz bin Silim ${ }^{1}$, Raja Norliza binti Raja Omar ${ }^{1}$, Jemaima Che Hamzah²

${ }^{1}$ Department of Ophthalmology, Hospital Melaka, Melaka, Malaysia; ${ }^{2}$ Department of Ophthalmology, Faculty of Medicine, Universiti Kebangsaan Malaysia, Kuala Lumpur, Malaysia

\section{Abstract}

Neuroretinitis is an inflammatory optic neuropathy with a classic funduscopic appearance of optic disc swelling and hard exudates on the macula in a star formation. It can be a manifestation of systemic, infectious or autoimmune disease. Here, we report three patients who presented with sudden onset of painless blurring of vision. Ophthalmic evaluation revealed a characteristic picture of neuroretinitis. Detailed study of the cases revealed leptospirosis being the aetiology of the neuroretinitis. Leptospirosis is a zoonotic infection caused by spirochetes Leptospira, which presents with both ocular and systemic manifestations. Neuroretinitis has been reported in the few cases of leptospirosis. We present three cases of leptospirosis with bilateral and unilateral neuroretinitis presenting with sudden loss of vision, optic disc oedema, and macular star. Leptospirosis was confirmed by serological test and the disease responded optimally to specific therapy. Although funduscopic examination showed marked inflammatory changes in the retina and optic nerve head, the recovery following medical treatment was remarkable.

Keywords: leptospirosis, macular star, neuroretinitis

Correspondence: Dr. Sangeetha Subramaniam, MD, Department of Ophthalmology, Hospital Melaka, Jalan Mufti Haji Khalil, 75400 Melaka, Malaysia.

E-mail: sans_0202@hotmail.com 


\section{Leptospira, pemangsa okular}

\section{Abstrak}

Neuroretinitis adalah neuropati optik radang dengan penampilan klasikal menunjukkan pembengkakan cakera optik dan eksudat keras pada makula dalam pembentukan umpama bintang pada fundus. Ia boleh menjadi sebahagian dari manifestasi penyakit sistemik, jangkitan kuman atau penyakit autoimun. Kami melaporkan tiga pesakit yang mengalami penglihatan kabur secara tiba-tiba tanpa rasa sakit . Penilaian oftalmik menunjukkan gambaran ciri neuroretinitis. Penyiasatan yang terperinci seterusnya menunjukkan leptospirosis menjadi etiologi bagi neuroretinitis dalam kesemua kes. Leptospirosis adalah jangkitan zoonosis yang disebabkan oleh spirochetes Leptospira, yang muncul dengan manifestasi okular dan sistemik. Neuroretinitis telah dilaporkan dalam beberapa kes leptospirosis. Kami mengemukakan tiga kes leptospirosis dengan neuroretinitis pada kedua belah mata dan satu kes yang mengalami kehilangan penglihatan secara tiba-tiba, edema cakera optik, dan pembentukan seperti bintang pada makula. Leptospirosis disahkan oleh ujian serologi dan penyakit ini bertindak balas secara optimum terhadap terapi spesifik yang diberikan. Walaupun pemeriksaan funduscopic menunjukkan perubahan keradangan pada retina dan kepala saraf optik, pemulihan setelah rawatan perubatan berlaku dengan baik sekali.

Kata kunci: bintang makula, leptospirosis, neuroretinitis

\section{Introduction}

Leptospirosis is a zoonotic infection caused by spirochetes of genus Leptospira. ${ }^{1}$ The disease has high incidence and prevalence in both developed and developing countries. Systemic features are common in the acute bacteraemic phase of the disease, whereas ocular features are common in the immunological phase. ${ }^{2}$ Thus, systemic features usually precede the ophthalmic complaints. There are only a few reported articles in the literature on Leptospira neuroretinitis. Here, we present three rare cases of neuroretinitis caused by leptospirosis.

\section{Materials and methods}

Case series. 


\section{Case presentation}

\section{Case 1}

A 13-year-old male with a ten-day history of painless blurring of vision in the right eye and mild fever was diagnosed with neuroretinitis. He had a history of swimming in a waterfall one month back. Ocular examination showed the best-corrected visual acuity (BCVA) was $6 / 60$ in both eyes. Anterior segment examination was normal and bilateral fundoscopy revealed oedematous optic disc with macular star (Fig. 1). Optical coherence tomography (OCT) of the macula showed bilateral

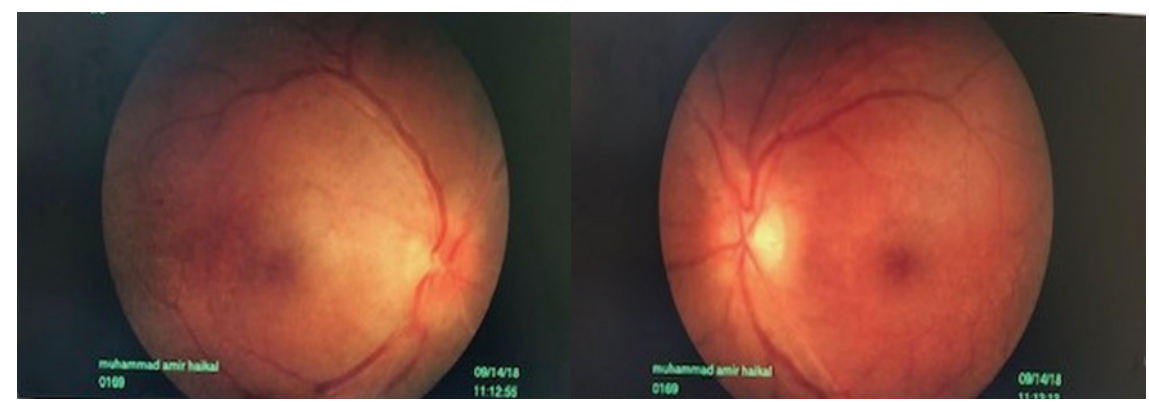

Fig. 1. Fundus examination showed bilateral swollen optic discs.
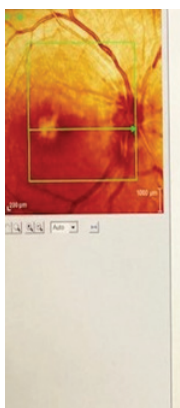
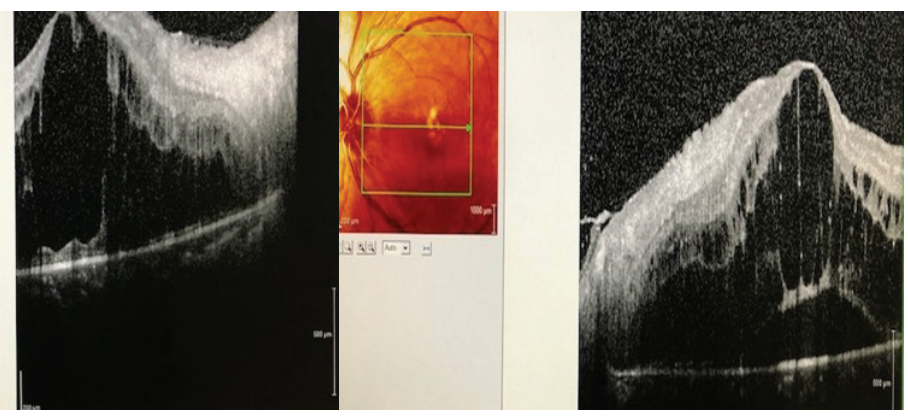

Fig. 2. Macular OCT showing bilateral macular oedema.

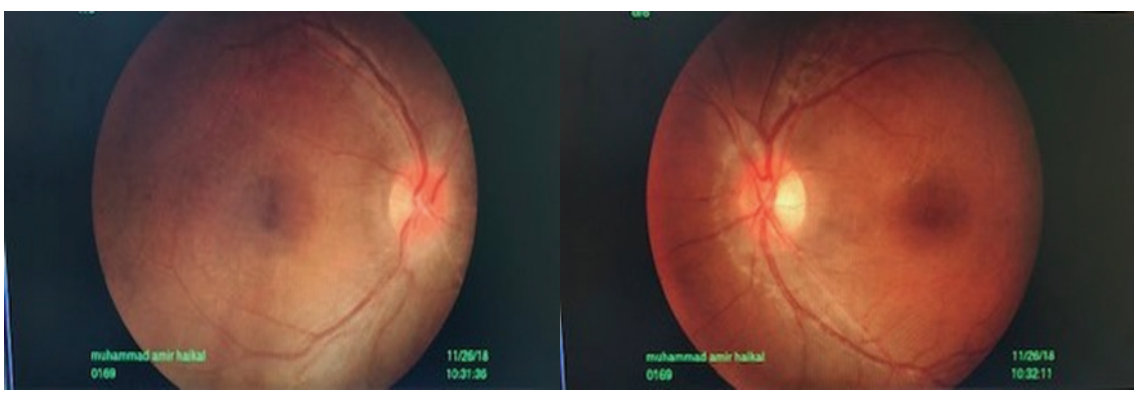

Fig. 3. Fundoscopy at 12 weeks of follow-up showing persistent bilateral disc oedema. 

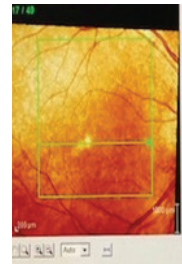
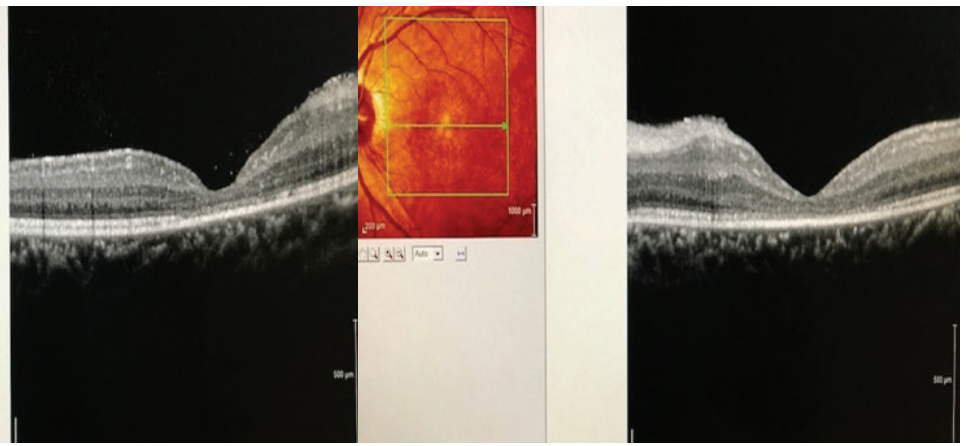

Fig. 4. Macular OCT at 12 weeks of follow-up showing resolution of macular oedema.

macular oedema (Fig. 2). Haematological investigations revealed mild leucocytosis. Microscopic agglutination test (MAT) for Leptospira serology was positive. He was treated with oral doxycycline $100 \mathrm{mg}$ twice a day for six weeks. After four weeks of follow-up, BCVA improved to 6/24 and 6/36 on the right and left eye, respectively. Bilateral fundoscopy revealed mild resolution of disc oedema and macular oedema. On follow-up after 12 weeks, bilateral BCVA improved to 6/18. There was almost total resolution of macular oedema (Fig. 3). However, the disc oedema persisted in both eyes (Fig. 4).

\section{Case 2}

This case involved a 20 -year-old male who presented with bilateral painless blurring of vision and redness for three days with a history of jungle trekking two weeks prior to presentation. On examination, BCVA of hand movement (HM) in the left eye and $6 / 18$ in the right eye were noted with impaired colour vision. There was presence of keratic precipitates with cells of $3+$ in both anterior chambers. Bilateral fundus examination revealed swollen, hyperaemic optic discs and star-shaped hard exudates on the macula (Fig. 5). Bilateral macular OCT showed subretinal and intraretinal fluid (Fig. 6). The clinical findings of anterior segment inflammation and optic disc oedema coupled with macular star were consistent with a diagnosis of panuveitis with neuroretinitis. Blood investigation revealed mild leucocytosis with neutrophilia, high erythrocyte sedimentation rate (ESR), and a positive Leptospira serology. The patient received oral doxycycline $100 \mathrm{mg}$ twice a day for six weeks, intravenous ceftazidime $1 \mathrm{~g}$ twice a day for two weeks, and oral prednisolone $30 \mathrm{mg}$ $(0.5 \mathrm{mg} / \mathrm{kg} / \mathrm{day})$ once daily, which was tapered to $5 \mathrm{mg}$ weekly. Guttae dexamethasone $0.1 \%$ and guttae atropine $1 \%$ were started for both eyes. The anterior segment inflammatory signs resolved within a few days and vision improved to 6/9 in both eyes after a period of two weeks. On the sixth week of follow-up, bilateral BCVA was $6 / 6$ with almost complete resolution of macular oedema (Fig. 7). However, the disc oedema still persisted in both eyes (Fig. 8). 


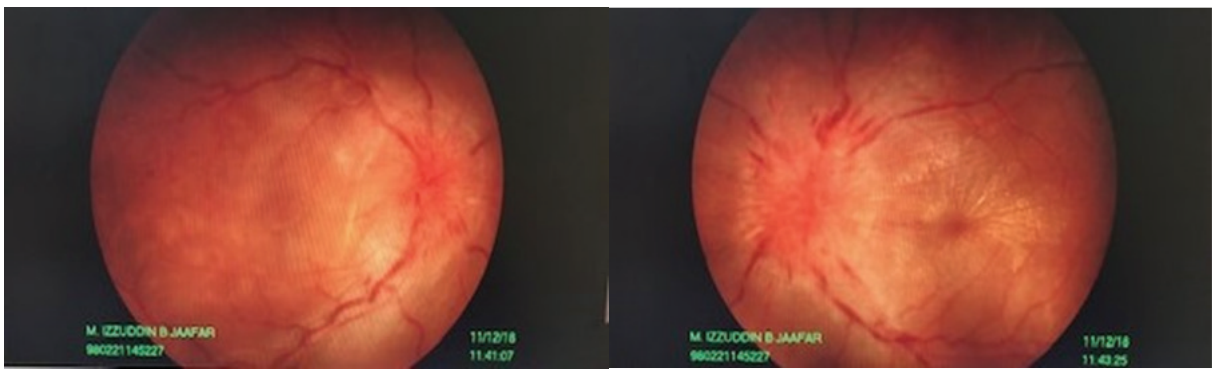

Fig. 5. Fundus photograph showing bilateral optic disc oedema with macular star.
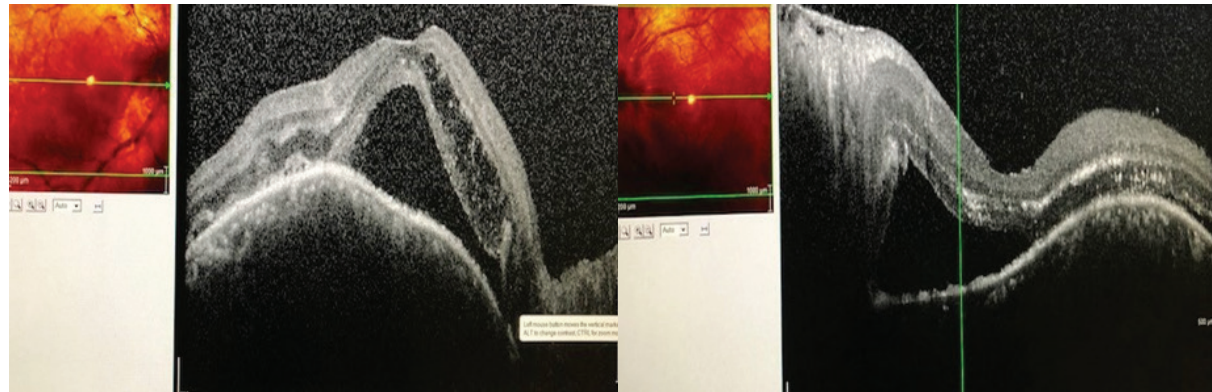

Fig. 6. Macular OCT showing macular oedema with subretinal fluid of both eyes.

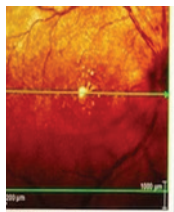

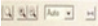
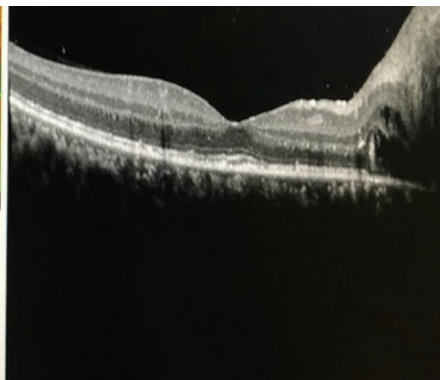
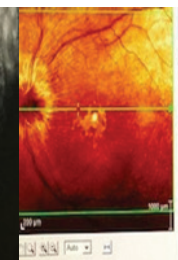

Fig. 7. Macular OCT at six weeks showing resolution of macular oedema.

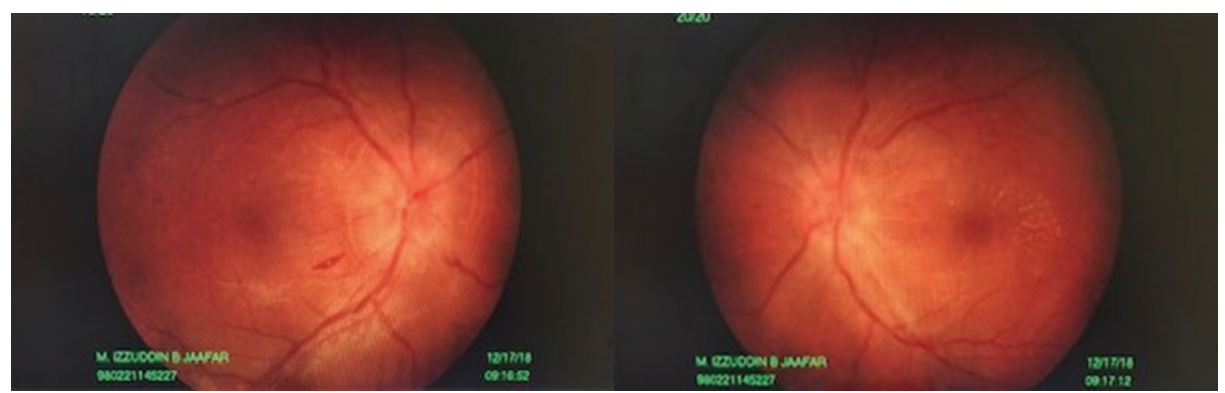

Fig. 8. Bilateral fundoscopy showing persistent optic disc swelling. 


\section{Case 3}

A 46-year-old female presented with a progressive decrease in vision in the left eye for three weeks. On examination, BCVA was $6 / 6$ in the right eye and 1/60 in the left eye. The left optic disc was hyperaemic, with blurred margins and presence of a macular oedema (Figs. 9 and 10). The patient developed stellate maculopathy two weeks later. Colour vision was severely impaired in the left eye. Visual fields of this patient revealed a centrocaecal scotoma in the left eye. The other eye was unre-

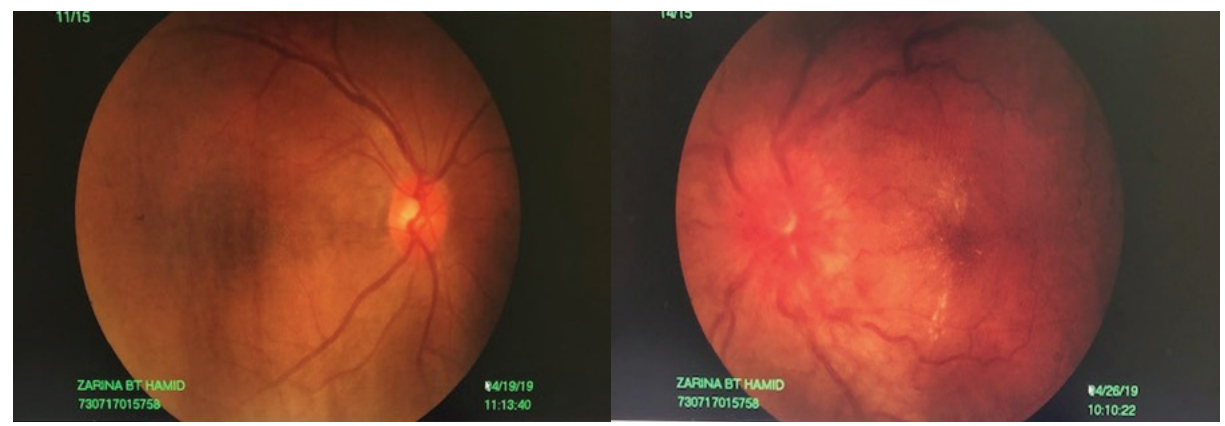

Fig. 9. Fundus photograph showing left optic disc oedema with macular star.
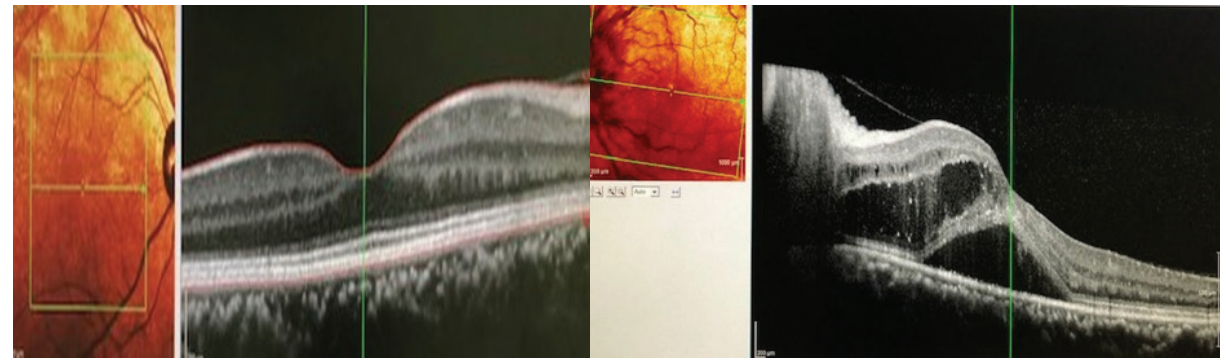

Fig. 10. Macular OCT of the left eye showing macular oedema with subretinal fluid.

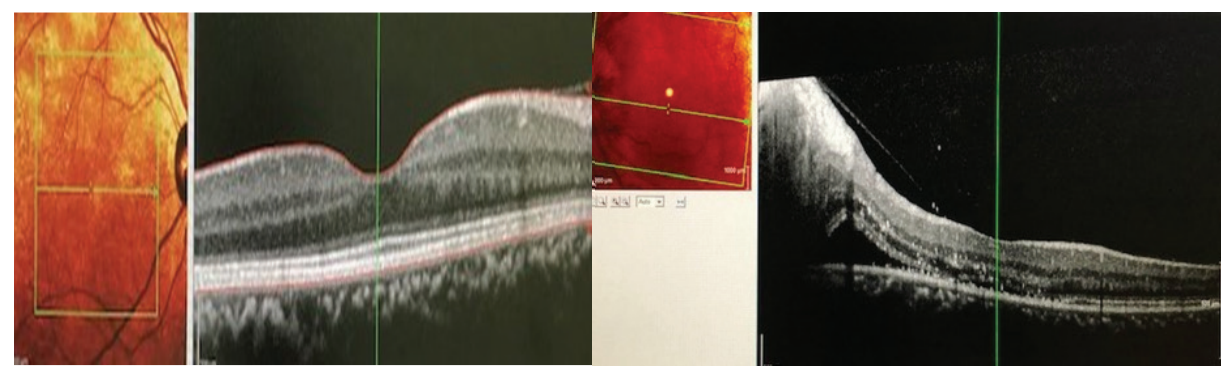

Fig. 11. Macular OCT macula at six weeks showing resolution of macular oedema in the left eye. 
markable in all aspects. Computed tomography of the brain and orbit was within normal limits. MAT for Leptospira serology was positive. Neuroretinitis secondary to leptospirosis was diagnosed. The patient was started on oral doxycycline $100 \mathrm{mg}$ twice a day for six weeks, along with tapering oral prednisolone. Six weeks after onset, the optic nerve swelling persisted, but the macular oedema had resolved (Fig. 11). The left-eye vision returned to 6/9.

\section{Discussion}

Neuroretinitis is a type of optic neuropathy characterised by an acute visual loss in the setting of optic disc swelling accompanied by star-shaped hard exudates around the fovea. The pathogenesis of neuroretinitis is associated with the direct involvement of the optic nerve fibres by the infectious process or the inflammation, leading to oedema and fluid exudation from the inflamed cellular area of the peripapillary retina.

Infections like syphilis, tuberculosis, cat-scratch disease, Lyme disease, hepatitis B, mumps, measles, toxoplasmosis, leptospirosis, and cysticercosis may cause neuroretinitis. ${ }^{3}$ Leptospirosis presents with both systemic and ocular manifestations. Neuroretinitis is an uncommon manifestation of the disease. Dreyer et al. first reported a case of neuroretinitis in leptospirosis. ${ }^{4}$ Later, Ray et al. ${ }^{3}$ and Rathinam et al. ${ }^{2}$ described similar cases.

The pathogenesis of leptospirosis is not well understood and is classified into two distinct phases: the direct effect of the organism during the bacteraemic phase and the host's response to an infection in the immunological phase. After entering the body, the organism invades the blood stream, resulting in a bacteraemia, disseminating into various organs such as the kidney, liver, lungs, heart, and central nervous system. ${ }^{2}$

The onset of systemic leptospirosis is characteristically abrupt, with severe headache, myalgia, chills, and rapidly rising temperature. Abdominal pain, retrobulbar pain, skin rash, and arthralgia are also seen. Ocular involvement in leptospirosis may occur during both the systemic bacteraemic and immunological phases. Ocular manifestations in an acute phase include conjunctival congestion without discharge, chemosis, or subconjunctival haemorrhage. ${ }^{5}$ Uveitis is an important complication of the late immunological phase, and hypopyon may occur when inflammation is severe. Other ocular immunological manifestations include interstitial keratitis, hyperaemic disc, membranous vitreous opacities, perivasculitis without vascular occlusion, retinal haemorrhage, and neuroretinitis. ${ }^{5}$ OCT has documented the evolving phases in neuroretinitis beginning with disc swelling, macular thickening, and subretinal fluid collection. This is followed 1-2 weeks later by spontaneous decrease in macular thickening and resorption of subretinal fluid. 
MAT is currently considered the gold-standard test. Laboratory testing should be tailored for every individual depending on the history and physical examination findings. Minimum laboratory work-up should include tests for tuberculosis, syphilis, and Bartonella species. Other tests that may be requested include serologies against viruses, bacteria, or protozoa (such as human immunodeficiency virus [HIV], toxoplasmosis, and Lyme disease), ESR, urinalysis, autoimmune panel, and blood cultures. In selected cases, neuroimaging and lumbar tap with cerebrospinal fluid analysis may be warranted.

Treatment of neuroretinitis is directed to the specific underlying cause. Appropriate antibiotic therapy is required for infectious aetiologies (secondary type) while idiopathic (primary type) neuroretinitis exhibits good spontaneous visual recovery and does not require any treatment. The role of steroids in treatment remains unclear in both the primary and secondary types. Management for Leptospira neuroretinitis in the past varied from observation to medical therapy with antibiotics alone or in combination with steroids. The antibiotics used were mainly a combination of quinolone (for its excellent intraocular penetration) and cyclines (to eliminate possible intracellular location of the organism) for a period of three weeks. Steroids have been used for Leptospira-associated neuroretinitis in the belief that it may hasten recovery of vision. ${ }^{6}$ However, there is no good evidence that it affects visual outcome. There are reports which show the administration of steroids in the acute phase or when the optic disc is involved. ${ }^{\text {? }}$

Our cases concern neuroretinitis with elevated Leptospira IgM. Route of entry was probably contaminated water during the trip to the waterfall and jungle trekking. The common ocular manifestations were not present in our case. Although steroids have no proven role on visual outcome, ${ }^{4}$ we used steroids in two of the cases to reduce the inflammatory response and to treat the underlying immune-mediated cause, which resulted in a better visual recovery and outcome. On completion of treatment, the visual response of our cases was satisfactory due to prompt aetiological diagnosis and management. As the pathogenesis of ocular infections and optic neuritis related to leptospirosis is still controversial, there is still no standardized treatment in managing ocular leptospirosis. A prospective multicentric study considering the aetiological factors and outcomes of the standardized treatment may provide a better insight into the aetiopathology, diagnosis, and management of Leptospira neuroretinitis.

\section{Conclusion}

Leptospirosis presenting as neuroretinitis without systemic manifestations has not been well reported or published. Hence, the knowledge of this condition and institution of prompt treatment may result in full visual recovery. 


\section{References}

1. Rathinam SR. Ocular leptospirosis. Curr Opin Ophthalmol. 2002:13:381-386.

2. Rathinam SR. Ocular manifestations of leptospirosis. J Postgrad Med. 2005;51:189-194.

3. Ray S, Gragoudas E. Neuroretinitis. Int Ophthalmol Clin. 2001;41:83-102.

4. Dreyer RF, Hopen G, Gass JD, Smith JL. Leber's idiopathic stellate neuroretinitis. Arch Ophthalmol. 1984;102:1140-1145.

5. Bernard N, Moshe H. Human leptospirosis associated with eye complications. Isr Med J. 1963;22:182.

6. Kodama T, Masuda H, Ohira A. Neuroretinitis associated with cat-scratch disease in Japanese patients. Acta Ophthalmol Scand. 2003;81:653-657.

7. Mahesh G, Giridhar A, Shedbele A, Kumar R, Saikumar SJ. A case of bilateral presumed chikungunya neuroretinitis. Ind J Ophthalmol. 2009;57: 148-150. 